ORNL/TM-2005/6

\title{
WORKSHOP ON FUNCTIONAL REQUIREMENTS FOR THE MODELING OF FATE AND TRANSPORT OF WATERBORNE CBRN MATERIALS
}

Gary E. Giles

January 2005 


\title{
DOCUMENT AVAILABILITY
}

Reports produced after January 1, 1996, are generally available free via the U.S. Department of Energy (DOE) Information Bridge.

Web site http://www.osti.gov/bridge

Reports produced before January 1, 1996, may be purchased by members of the public from the following source.

\author{
National Technical Information Service \\ 5285 Port Royal Road \\ Springfield, VA 22161 \\ Telephone 703-605-6000 (1-800-553-6847) \\ TDD 703-487-4639 \\ Fax 703-605-6900 \\ E-mail info@ntis.fedworld.gov \\ Web site http://www.ntis.gov/support/ordernowabout.htm
}

Reports are available to DOE employees, DOE contractors, Energy Technology Data Exchange (ETDE) representatives, and International Nuclear Information System (INIS) representatives from the following source.

Office of Scientific and Technical Information

P.O. Box 62

Oak Ridge, TN 37831

Telephone 865-576-8401

Fax 865-576-5728

E-mail reports@adonis.osti.gov

Web site http://www.osti.gov/contact.html

This report was prepared as an account of work sponsored by an agency of the United States Government. Neither the United States government nor any agency thereof, nor any of their employees, makes any warranty, express or implied, or assumes any legal liability or responsibility for the accuracy, completeness, or usefulness of any information, apparatus, product, or process disclosed, or represents that its use would not infringe privately owned rights. Reference herein to any specific commercial product, process, or service by trade name, trademark, manufacturer, or otherwise, does not necessarily constitute or imply its endorsement, recommendation, or favoring by the United States Government or any agency thereof. The views and opinions of authors expressed herein do not necessarily state or reflect those of the United States Government or any agency thereof. 
ORNL/TM-2005/6

\section{COMPUTATIONAL SCIENCES AND ENGINEERING DIVISION}

\section{WORKSHOP ON FUNCTIONAL REQUIREMENTS FOR THE MODELING OF FATE AND TRANSPORT OF WATERBORNE CBRN MATERIALS}

Gary E. Giles

January 2005

Prepared by

OAK RIDGE NATIONAL LABORATORY

Oak Ridge, Tennessee 37831-6085

managed by

UT-BATTELLE, LLC

for the

U.S. DEPARTMENT OF ENERGY

under contract DE-AC05-00OR22725 



\section{CONTENTS}

\section{Page}

ACKNOWLEDGEMENTS

V

ABSTRACT vii

1. INTRODUCTION

2. ATTENDEES

1

3. PRIORITIZED REQUIREMENTS 3

4. CONCLUSIONS 3

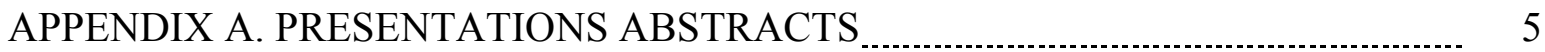

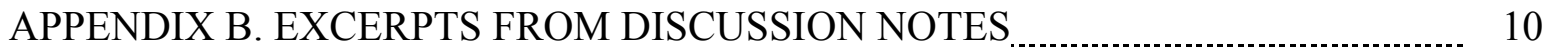




\section{ACKNOWLEDGEMENTS}

The Workshop on "Functional Requirements for the Modeling of Fate and Transport of Waterborne CBRN Materials" was successful due to the help of the following people and organizations. First of all, to thanks to the attendees who gave their time and expertise because they wanted the Workshop to be of benefit. Their interest in furthering the capabilities of modeling in this area reflects their desire to provide the country with the ability to protect against attacks and releases into the water system. Ben Bryan of NCI was extremely helpful in bringing his previous experience in developing workshops, in developing the list of attendees, and in making contacts. Brian Worley had the foresight to suggest this type of workshop and he and Donna Poole provided a lot of support in developing the Workshop. David Hetrick provided a lot of insight and helped direct the workshop. Andrea Sjoreen's knowledge and experience were also necessary to the success of the workshop. 


\begin{abstract}
The purpose of this Workshop on "Functional Requirements for the Modeling of Fate and Transport of Waterborne CBRN Materials" was to solicit functional requirements for tools that help Incident Managers plan for and deal with the consequences of industrial or terrorist releases of materials into the nation's waterways and public water utilities. Twenty representatives attended and several made presentations. Several hours of discussions elicited a set of requirements. These requirements were summarized in a form for the attendees to vote on their highest priority requirements. These votes were used to determine the prioritized requirements that are reported in this paper and can be used to direct future developments.
\end{abstract}




\section{INTRODUCTION}

Oak Ridge National Laboratory (ORNL) has been tasked to develop a suite of water transport models for homeland security and emergency response applications. To ensure that these models are as useful as possible to homeland security and emergency response personnel, ORNL hosted a workshop to determine the users' requirements for models of contaminant transport in waterways. ORNL and the University of Florida (its research partner) have developed a system, Hydrologic Transport Assessment System Curvilinear Hydrodynaics One Dimensional (HYTRAS/CH1D), that models transport of nuclear and chemical materials in rivers and estuaries. HYTRAS/CH1D is a screening model; higher fidelity models are presently being developed. A range of models is planned, from quick-running, screening-level models for emergency response, to high-fidelity three-dimensional models for planning and assessments. In planning the future enhancements to these models, the real needs of the user community are of primary importance and must be thoroughly understood. It is envisioned that the systems developed will be applied to port security, public water supply intakes, inland shipping, and other uses of water bodies. From this workshop we learned the needs that users for Incident Management (IM) of contaminant release in the nation's waterways.

The workshop, held at ORNL on September 22, 2004, involved twenty representatives from twelve organizations, with eleven presentations and several hours of discussion in a one-day workshop. The list of attendees is contained in Sect. 2. The titles and abstracts of the presentations are given in App. A. Appendix B contains excerpts from the discussions that were sent to the attendees for them to prioritize a list of functional requirements. The prioritized list is reported in Sect. 3. Conclusions from the workshop are reported in Sect. 4.

\section{ATTENDEES}

Table 1 summarizes the organizations that sent representatives, while Table 2 contains the name and contact information for each attendee.

Table 1. Organizations Represented

US Coast Guard (USCG)

US Navy/Naval Oceanographic Office (USN/NOO)

US Environmental Protection Agency (USERA)

Tennessee Valley Authority (TVA)

National Oceanic and Atmospheric Administration (NOAA)

Defense threat Reduction Agency (DTRA)

Department of Homeland Security (DHS)

University of Florida (UF)

Oak Ridge National Laboratory (ORNL)

US Geological Survey (USGS)

$\mathrm{NCI}$ information Systems, Inc. (NCI)

Scientific Applications International Corporation_(SAIC) 
Table 2. Attendee List

\begin{tabular}{|c|c|c|c|}
\hline NAME & Organization & Office Phone & Email Address \\
\hline Thomas Alford & TVA & $865-632-7488$ & thalford@tva.gov \\
\hline CDR Scott Beeson & $\begin{array}{l}\text { USCG Marine Safety } \\
\text { Office }\end{array}$ & $843200-8755$ & sbbeeson@mhscharleston.uscg.mil \\
\hline Dr. Robert Borowski & $\begin{array}{l}\text { Homeland Security } \\
\text { Institute }\end{array}$ & (703) 416-3241 & Robert.Borowski@hsi.dhs.gov \\
\hline Ben Bryan & $\begin{array}{l}\text { NCI part-time Support } \\
\text { Contractor }\end{array}$ & $865241-6243$ & bkbryan@nciinc.com \\
\hline Dr. Justin R. Davis & $\begin{array}{l}\text { U of FL, Civil \& Coastal } \\
\text { Engineering Department }\end{array}$ & $\begin{array}{l}352-392-1436 \\
\times 1528 \\
\end{array}$ & davis@coastal.ufl.edu \\
\hline Kyle R. Dedrick & $\begin{array}{l}\text { Contractor, NGIT Defense } \\
\text { Threat Reduction Agency }\end{array}$ & $\begin{array}{l}703-325-6448 / \\
7043\end{array}$ & kdedrick@cnttr.dtra.mil \\
\hline G. Robert Doenges, Jr. & SAIC & $703-676-8066$ & g.robert.doenges.jr@saic.com \\
\hline Gary Giles & UT-Battelle / ORNL & $865-574-8667$ & gilesgejr@ornl.gov \\
\hline Mr. Steven D. Haeger & $\begin{array}{l}\text { Naval Oceanographic } \\
\text { Office Stennis Space } \\
\text { Center }\end{array}$ & & haegers@navo.navy.mil \\
\hline Dr. Michael T. Koterba & USGS & 4102384240 & $\begin{array}{l}\text { mkoterba@usgs.gov } \\
\text { mkoterba@comcast.net }\end{array}$ \\
\hline Bob Morris & UT-Battelle / ORNL & $865-576-5878$ & morrisrh@ornl.gov \\
\hline Dr. Krish Namboodiri & $\begin{array}{l}\text { NCI part-time Support } \\
\text { Contractor }\end{array}$ & $703489-9472$ & krishn@nciinc.com \\
\hline Kathleen Nickel & $\begin{array}{l}\text { U.S. Environmental } \\
\text { Protection Agency } \\
\text { Homeland Security } \\
\text { Research Center } \\
\end{array}$ & (513) 569-7955 & Nickel.Kathy@epamail.epa.gov \\
\hline Dave Hetrick & UT-Battelle / ORNL & $865-576-7556$ & hetrickdm@ornl.gov \\
\hline Robert D. Quinn & ORNL & $865-574-1051$ & quinnrd@ornl.gov \\
\hline Dr. William B. Samuels & SAIC & $703-676-8043$ & samuelsw@saic.com \\
\hline Prof. Peter Sheng & $\begin{array}{l}\text { U of FL, Civil \& Coastal } \\
\text { Engineering Department }\end{array}$ & \begin{tabular}{|l|}
$352-392-1436$ \\
$352-392-9537)$ \\
Ext 1521
\end{tabular} & pete@coastal.ufl.edu \\
\hline Andrea Sjoreen & UT-Battelle / ORNL & $865-574-5333$ & sjoreenal@ornl.gov \\
\hline Dr. Eugene Wei & $\begin{array}{l}\text { NOAA's National Ocean } \\
\text { Service }\end{array}$ & $\begin{array}{l}(301) \\
\mathrm{x} 102\end{array}$ & eugene.wei@noaa.gov \\
\hline $\begin{array}{l}\text { Dr. Brian Worley } \\
\text { Keynote speaker }\end{array}$ & $\begin{array}{l}\text { UT-Battelle / ORNL, } \\
\text { Computational Sciences } \\
\text { and Engineering }\end{array}$ & $865-574-6106$ & worleyba@ornl.gov \\
\hline
\end{tabular}




\section{PRIORITIZED REQUIREMENTS}

These requirements were solicited from the attendees by supplying them with the excerpts of the notes from the meeting (App. B). The respondents listed their requirements in priority order. These lists were combined and the priority of each item was determined by the number of votes for each item.

The five top requirements are:

1. Incident Management (IM) Tools must provide quality data, good estimates of damage, and the results must be easily understood and communicated.

2. There must be a federally funded Rapid Response Analysis Center (RRAC) for water transport and fate of CBRN materials.

3. The RRAC and other entities will need access to Department of Homeland Security (DHS)/Advanced Scientific Computing resources in order to provide timely emergency analysis.

4. RRAC and local IM centers will need to develop and maintain databases of water body geometries, flow conditions and extensive pre-incident simulations. These databases will enable the development of planning Hazards Maps. A Hazards Map will enable the IM team to develop an understanding of where the port is most vulnerable and where resources must be concentrated to minimize consequences. The Hazards Map should also enable the IM team to proactively develop interdiction and emergency plans.

5. The RRAC and IM teams should have a spectrum of analysis tools. The first level of tool would be rapid-response models designed for the IM centers direct use to get answers within minutes. The RRAC should have available intermediate models that can give more accurate answers in tens of minutes. The RRAC should be able to call on expert resources that can use higher fidelity models and more powerful computers to give even more accurate answers if needed. All of these tools should include the ability to back-extrapolate from the measured data to a best guess of the release location, time, and amount.

\section{CONCLUSIONS}

The discussions held at the workshop indicate a significant lack of tools and capabilities that are needed to protect the nations waterways.

There is a need for water-borne transport models in a variety of governmental organizations. Many models exist, but no one "does it al."

Modeling water-borne transport with the accuracy required for IM applications requires data that is frequently unavailable.

The requirements developed can be a useful guide to present and future projects. 
However, the requirement for a Rapid Response Analysis Center will need to be addressed at a higher level (DHS?) and is not a specific requirement for tool development. 


\section{APPENDIX A. PRESENTATION ABSTRACTS}

Welcome To ORNL

Brian Worley

Computational Sciences and Engineering Division Head

Oak Ridge National Laboratory

Oak Ridge, TN, 37831-6082

A brief description of ORNL in general and the specific capabilities of the Laboratory to support the water modeling projects.

\section{Purpose And Scope Of This Workshop}

And

HYTRAS Modeling Transport Of CBRN Materials In Rivers And Estuaries

Gary Giles

Modeling and Simulation Group

Computational Sciences and Engineering Division

Oak Ridge National Laboratory

Oak Ridge, TN, 37831-6085

The first talk explains the purpose of the workshop is to acquire information from users so that future developments can be more effective tools.

The second talk describes the HYTRAS tool development project.

HYTRAS is being developed to provide Incident Management teams with transport and fate of CBRN materials released into waterways. HYTRAS includes three different river models with runoff models and sediment models to provide an estimate of the concentration of CBRN materials within a river/estuary system. The Graphical User Interface allows easy description of the release and displays the results in an easy to understand manner. The tool currently handles river systems and one specific type of estuary system. HYTRAS is being extended to handle more estuary/lake/bay systems.

\section{Overview Of The Modeling Efforts Of The EPA Homeland Security Research Center}

Kathleen Nickel

U.S. Environmental Protection Agency

Homeland Security Research Center

26 W. Martin Luther King Blvd.

Cincinnati, OH 45268

(513) 569-7955

Nickel.Kathy@epamail.epa.gov

Brief overview of the modeling efforts in protecting the nation's public water systems from industrial accident or terrorist attack. 
Brief Overview of Coast Guard Marine Security Needs in Charleston Harbor

CDR Scott Beeson

US Coast Guard Marine Safety Office

196 Tradd Street, Charleston, SC 29401

sbbeeson@mhscharleston.uscg.mil

Brief description of Project Seahawk and the multi-agency port security prototype being developed in Charleston harbor.

\author{
An Overview Of University of Florida's Capabilities In Contaminant \\ Transport/Dispersion Modeling \\ Dr. Peter Sheng \\ PI on HYTRAS Modeling \\ U of FL, Civil \& Coastal Engineering Department \\ P.O. Box 116580 \\ University of Florida \\ Gainesville, FL 32611-6580 \\ 352-392-1436 and 352-392-9537 ext. 1521 \\ pete@coastal.ufl.edu
}

Brief review of the extensive modeling effort of the Coastal Engineering Department at the University of Florida including many of the estuaries and water bodies in Florida.

\title{
A Simple Transport/Dispersion Model For Estuarine/Riverine Systems
}

Dr. Justin R. Davis

Modeler on HYTRAS

Post-Doctoral Research Associate

P.O. Box 116580

University of Florida

Gainesville, FL 32611-6580

352-392-1436 ext.1528

davis@coastal.ufl.edu

A brief description of the HYTRAS/CH1D model developed at the University of Florida and an application to the Lower St. Johns River estuary system. This simulation used driving boundary conditions driven by the tidal conditions. The model was validated on a 60-day period of historical data (wit a 30 day spin-up period) with very good results for general flow and reasonable results for salinity conditions modeling. 


\section{Operational Estuarine And Coastal Forecast Model Systems In NOAA’s Ocean Service}

Eugene Wei, Ph.D.

NOAA/NOS/CSDL/MMAP

1315 East West Highway, N/CS13

Silver Spring, MD 20910

(301) 713-2809 ext. 102

eugene.wei@noaa.gov

NOAA's National Ocean Service (NOS) develops estuarine and coastal hydrodynamic models (driven by real-time in situ and remote data and the outputs of weather forecast models) and transitions them to a 24/7 quality-controlled operational environment to produce nowcasts and forecasts for a variety of applications. These model systems support safe and efficient navigation (e.g., forecast water level fields for under-keel clearance), emergency response (e.g., circulation and density fields for oil spill trajectory forecasts and solute dispersion predictions), as well as other marine geospatial and ecosystem applications. Nowcast/forecast systems are presently running operationally for the Chesapeake Bay, the Port of New York and New Jersey, and Galveston Bay, with others in development for the St. Johns River, FL, and Cook Inlet, AK. Additional models developed outside NOS will also be transitioned to operations, for areas such as the Great Lakes, Tampa Bay, and the Columbia River. Boundary conditions are provided by coastal forecast models developed in-house and from other agencies. Critical to the efficient and skillful operation of these many operational forecast models (which will someday cover all major U.S. bays and ports), is a standardized and modularized operating system called the Coastal Ocean Modeling Framework, that models must fit into, and that deals with all aspects of inputing real-time data and forecasts from weather, hydrological, and coastal models, as well as standardized, user-friendly outputs. Improvements to the forecast skill of these model systems will be an ongoing effort, including the use of data assimilation and ensemble averaging, the latter technique being one approach to the important problem of estimating the uncertainty of individual forecasts.

\section{Functional Requirements For CBRN Fate And Transport Modeling At The Naval Oceanographic Office}

Steven D. Haeger

Naval Oceanographic Office

228-688-4457

haegers@navo.navy.mil

The Ocean Models and Forecasting Divisions at the Naval Oceanographic Office (NAVOCEANO) implement and run several types of 2- and 3-dimensional circulation models for many geographical domains around the world. Most of these are run in an operational mode and generate products daily for the Fleet. The model products, which include currents, elevations, temperature, and salinity, support a wide variety of applications ranging from Special Operations, Mine Warfare, Object Drift, Search and Rescue, and Oil Spill. We anticipate additional future resources to support operational contaminant fate and transport modeling for the Navy and DoD. This support will most likely be to provide 
predictions of currents from our operational models in foreign areas to drive contaminant transport models run by other agencies or by field personnel. Functional requirements will emphasize linking newly developed contaminant fate/transport models to operational circulation models (existing and new) and to meteorological models.

\section{Pipelinenet, Riverspill And Icwater (Incident Command Tool For Drinking Water Protection.}

William B. Samuels, Ph.D

Senior Scientist

Hazard Assessment and Simulation Division

Science Applications International Corporation

1410 Spring Hill Road

McLean, VA 22102

phone: 703 676-8043

fax: $703676-8025$

A set of GIS-based waterborne transport tools has been developed that simulate the fate and transport of contaminants in source water and within the distribution system. These tools consist of: (1) the Incident Command Tool for Drinking Water Protection (ICWater), RiverSpill - real-time, time-of-travel and dispersion model, and (3) PipelineNet - water distribution hydraulic and water quality model.

ICWater integrates multiple sources of information to give decision makers concise summaries of current conditions and forecasts of future consequences of terrorist acts on public water supply safety. The system will be GIS-based and the output will be compatible with the Defense Threat Reduction Agency's (DTRA) Consequences Assessment Tool Set (CATS), the Federal Emergency Management Agency's HAZUS system, the Environmental Protection Agency's Situation Room, and the TSWG sponsored Chemical Biological Response Aid (CoBRA). The core element of ICWater is the RiverSpill time-of-travel model. RiverSpill is being modified to operate at the 1:100,000-scale stream network available through the EPA and USGS National Hydrography Dataset (NHD). RiverSpill is a GIS-based tool that provides the ability to model, using real-time stream flow data, the timeof-travel and concentration of toxic substances at public water supply intakes. The system uses a hydrologically connected stream network integrated with USGS gages and public water supply intakes. PipelineNet is a GIS-based system, that integrates hydraulic and water quality models with existing spatial databases. PipelineNet integrates EPANET and ArcView to give emergency managers real time information estimating the risks to public water supplies. This integration gives PipelineNet all the computational (hydraulics and water quality) capabilities of EPANET and all the functionality of ArcView. The integrated system calculates, locates, and maps the population at risk from the introduction of contaminants to the public water supply distribution network. 


\section{A Brief Overview Of U.S. Geological Survey Contributions To Fate And Transport Modeling Of Contaminants With Focus On Surface Water}

Dr. Michael T. Koterba

U.S. Geological Survey

MD-DE-DC District

Patuxent Wildlife Research Center

8987 Yellow Brick Rd.

Beltsville Lab, C/O BARC _East Bldg 308

10300 Baltimore Avenue

Baltimore Md.

Tel $4102384240 \quad$ Beltsville, Md 20705

Fax 4102384210 Tel 3014975923

mkoterba@usgs.gov,mkoterba@comcast.net

The U.S. Geological Survey (USGS) performs a range of monitoring and research programs related to: the fate and transport of chemical, biological, radiological, or nuclear contaminants in surface water; water-quantity and water-quality monitoring; ground-water modeling; ground-water/surface-water inter-actions research and modeling; and surfacewater modeling. Modeling both involves short and long term scales including rapid response modeling. The programs and research are greatly aided by the USGS network of over 7,000 near real-time streamgages and real-time water quality networks of surface and ground water sites. In general, the USGS hydrologic monitoring data are avail-able at http://waterdata.usgs.gov/nwis. The USGS recognizes the importance and concern of ground-water withdrawal as a pathway for contaminants into drinking water, as illustrated by the research of Ingrid Verstraeten and others. The USGS models pollutant transport in surface water in many areas throughout the nation as illustrated by the research of Ken Bencala, Rob Runkel, Gene Parker, Richard Moore, and Rick Webb. Rapid-response modeling by the USGS is best depicted in examples from San Francisco Bay conducted by Ralph Cheng, Rick Signell, and Pete Smith, which is the primary focus of the USGS presentation. 


\section{APPENDIX B. EXCERPTS FROM DISCUSSION NOTES}

These excerpts provide a more detailed reporting of the discussions and are included here as

additional items that may (for a specific project) become more important than the "Top Five" list reported in Sect. 3.

\section{GENERAL OR COMMON REQUIREMENTS}

- Federal government funding of rapid response analysis centers (RRAC)

- Support local incident management centers (IMC) with detailed calculations and advice in a timely manner.

- Deliver quality data to the IMC

- Be able to explain the nature of, and quantify, any uncertainty in the simulation estimates of effects.

- Minimize flooding of IM with unvetted data/estimates.

- Extensive library of previously run simulations.

- So that an IMC can develop a pre-generated estimate of probability of damage from a release at any point in the system and to identify most important threats.

- This also allows the development of a prepared "playbook" of prioritized responses.

- In addition, because we are dealing with many uncertainties, extensive sensitivity studies (both Monte Carlo and ensemble) have to be done to help prioritize threats and determine which parameters have the most influence? (e.g., absorption coefficient, $\mathrm{K}_{\mathrm{d}}$ has huge impact for groundwater models, some models depend on data that is hard to determine in the real world.) Analytical distillation of these studies could extend the usefulness of the library.

- Experimental validation of these simulations would allow the IMC to determine which simulation tool is applicable in their region of interest.

- IMC and RRAC together need a spectrum of simulation tools (models/codes/systems).

- Need three levels of response times.

- Immediate [(ala RiverSpill or HYTRAS) to be used by IMC or RRAC].

- Rapid response [( 2 hours) to be used by RRAC or IMC],

- Full physics [(HYTRAS/CH3D) to be used by RRAC],

- The more detailed and the more physics intensive codes should be applicable to more waterways but will require more highly trained personnel, data, and computational resources. Full-physics models must be deployed well ahead of an incident so that the responsible staff can become familiar with running the models, know which simulation tool best matches the local conditions, and develop an understanding of, and confidence in, the models (validation). The full-physics tools would be more appropriate to a RRAC unless the local IMC wants to develop and pay for the capability.

- Quick response calculations must still have the necessary physics. 
- Too simple physics can give inaccurate and dangerous results. The modeled physics must be appropriate for each scenario. The dispersion model is important. Integrating hydrodynamic models with dispersion models is the key and is complicated - need dispersion models that can integrate with various hydrodynamics models.

- Inverse capability - extrapolate backwards to the probable source.

- Estimation of probable source will improve forecasts of dispersion and fate, allow interdiction of further releases, and direct potential police actions.

- Consistent use of data between models.

- For example, in a hypothetical, multi-component system such as HPAC/HYTRAS/CH1D, the same weather data should be used in the air and water dispersion calculations.

- Determine the chemistry of MWD materials within water.

- Water pH and chemistry can ameliorate greatly the affects of such agents in water but there is not much data.

- Integrate the hydrodynamic codes with GIS and sensors.

- Although ESRI data formats and GIS are getting to be more common in IM centers, it is not clear what will be the most common system of choice in the future. Designing components to be used within all possible GIS is problematic. Data transfer must be transparent.

- Use remote sensing data to validate the hydrodynamic and dispersion codes.

Some of the following requirement descriptions could probably be classed as general but are listed in the section in which they were first mentioned.

\section{EPA REQUIREMENTS}

- New sensors for water system protection. EPA is very interested in new sensors and is evaluating current sensor effectiveness.

- Methodology to determine impact or health effects of contaminant.

- Probabilistic analyses.

- Multi species.

- Help water utilities determine where to place their sensors?

- Threat assessment in water supply to population.

- GIS to determine population and infrastructure affected.

- Good estimates of probabilities of damage are necessary. Water utilities do not want to shut down unless it is vital. Relying on a model that is overly conservative is undesirable. Complete shut down of water system is sometimes difficult or restart can take a long time and/or be expensive.

- Validate simulations using surrogates, dyes, whenever possible.

- Develop a library of chemical species that appear in waterways.

\section{NAVY REQUIREMENTS}

- World-wide modeling. 
- Requires the widest selection of models/systems (e.g., multiple hydrodynamic models and dispersion and fate models). A model may be adequate for some but not all locations. Although some world-wide modeling capabilities exist, any new development must be able to meet this need.

- Input data descriptions and output display must be tailored to the expertise of nominal users:

- Are they scientists? How much in-depth understanding of the data is needed? Primary display of simulation results must be easy to understand and easy to communicate to the public. More detailed results must be available for expert scrutiny to assess the validity of the simulations and/or input.

- Do not restrict transport/fate data and models to a particular circulation model.

- Immediate access, pre-existing database of currents and conditions.

- This database should span a wide range of environmental conditions such as seasonally typical conditions and abnormal (storm/flood) conditions to facilitate interdiction planning and/or realistic training. Environmental changes such as channel dredging or storm modification will require vigilance in maintaining such a database. Data mining and vetting are time consuming and therefore must be done before an incident. These activities are also expensive and thus care must be taken in selecting sites for data mining activities.

\section{USGS REQUIREMENTS}

- Model sediment loads and sedimentation.

- Model groundwater (rivers and aquifers) to assist in maintaining security.

- Grossly underestimated as being important.

- Be able to discern between several models that may give different answers.

- Frozen estuary modeling.

\section{USCG REQUIREMENTS}

- Identify data repositories for simulations

- Geometric data (shorelines, bathymetry, currents, tides, GIS (population and infrastructure), properties of released agents and "background" species, chemistry, etc. Maintain links to all data repositories. Identify missing data and develop plans to acquire.

- Integrate stakeholders for maritime security.

- CG, police, state, city, port authorities, etc. Develop a clear understanding of who will respond and how? Who will deploy boats to investigate, interdict, and to perform remedial actions?

- Quick response to all incidences.

- Minimize false alarms.

- Endangers personnel and negatively affects public.

- Build detection system around port

- Establish background radiation levels and resident chemical species.

- Operational use of LandScan data for population affected, evacuation plans, etc. 
- Engage models extensively in a planning mode. Be prepared.

- Continue work on remotely piloted vehicles as sensor platform.

- CG is working with RP vehicles (Jet-Ski) with sensors.

- Port oriented centers - each one to identify appropriate tools.

- (e.g. inland rivers and estuaries are totally different problems.)

\section{TVA REQUIREMENTS}

- System must be bullet proof with a high level of confidence.

- Simulation results must be easy to understand and easy to communicate to public.

- IM most likely a CEO level decision maker.

- Tools must be use in extensive planning.

- Assist in dealing with state HWY patrols, police, DHS, etc.

- Have many plans for many different scenarios.

\section{DTRA REQUIREMENTS}

- Shape file output

- Surface waves affects on transport and resuspension

- Integration of HYTRAS with SCIPUF (HPAC)

- To assess hazardous spills into rivers/estuaries and subsequent evaporation and atmospheric transport, followed by re-deposition into water, etc.; also, tidal effects in estuaries...tidal pooling can isolate contaminants as a "liquid pool" source for re-evaporation.

- Capturing dynamic models for estuaries near military installations. 2D or 3D are preferred to $1 \mathrm{D}$ tools.

- Effects on water transport of materials due to munitions effects on dams, locks and waterways 


\section{ORNL/TM-2005/6}

\section{INTERNAL DISTRIBUTION}

1. B. L. Budhendra

2-6. G. E. Giles

7. A. R. Ganguly

8. D. M. Hetrick

9. R. H. Morris

10. R. D. Quinn

11. A. L. Sjoreen

12. B. A. Worley

13. Central Research Library

14. ORNL Laboratory Records - RC

15. ORNL Laboratory Records - OSTI

\section{EXTERNAL DISTRIBUTION}

16. Thomas Alford, TVA, thalford@tva.gov

17. CDR Scott Beeson, USCG Marine Safety Office, 196 Tradd St., Charleston, SC 29401

18. Dr. Robert Borowki, Homeland Security Institute, 2900 South Quincy St. Ste. 800, Arlington, VA 22206

19. Bejamin Bryan, NCI, bkbryan@nciinc.com

20. Dr. Justin R. Davis, Univeristy of Florida, Civil and Coastal Engr. Dept.,

P.O. Box 116580, Gainesville, FL 32611-6580

21. Kyle R. Dedrick, NGIT Defense Threat reduction Agency, kdedrick@cnttr.dtra.mil

22. Robert Doenges, Jr., SAIC, 1410 Spring Hill Rd., MS SH-2-1, MCLean, VA 22102

23. Mr. Steven Haeger, Naval Oceanographic Office, Stennis Space Center, haegers@navo.navy.mi

24. Dr. Michael T. Koterbya, US Geological Survey, MD-DE-DC District, 8987 Yellow Brick Rd., Baltimore, MD

25. Dr. Krish Namboodiri, NCI, krishn@nciinc.com

26. John Nasstrom, LLNL, jnasstrom@,llnl.gov

27. Kathleen Nickel, USEPA, Homeland Security Research Center, 26 W. Martin Luther King Blvd., Cincinnati, OH 45268

28. Dr. William B. Samuels, SAIC, 1410 Spring Hill Rd., McLean, VA 22102

29. Prof. Peter Sheng, University of Florida, Civil and Coastal Engineering Dept., P.O. Box 116580, Gainesville, FL 32611-6580

30. Dr. Eugene Wei, NOAA National Ocean Service, 1315 East West Highway, N/CS13, Silver Spring, MD 20910

31. Harry L. Jenter, USGS, 12201 Sunrise Valley Dr., MS 420, National Center, Reston, VA 20192. 